\title{
PERAN KELUARGA DAN PETUGAS KESEHATAN TERHADAP LAMA MENYUSUI BAYI
}

\author{
FAMILY ROLE AND HEALTH CARE OFFICERS AT DURATION OF BREASTFEEDING INFANTS
}

\author{
Jenny J S Sondakh ${ }^{1}$, Ita Yuliani ${ }^{2}$ \\ 1,2 Jurusan Kebidanan Poltekkes Kemenkes Malang \\ Email Korespondensi : sondakhjenny@gmail.com
}

\begin{abstract}
Abstrak
Indonesia merupakan salah satu negara berkembang dengan Angka Kematian Bayi (AKB) tinggi. AKB tahun 2017 sebanyak 10.294 kasus (Kemenkes RI) dan disebabkan oleh infeksi dan hipotermi. Inisiasi menyusui dini (IMD) dan ASI eksklusif adalah satu upaya penurunan infeksi penyebab AKB, karena ASI eksklusif memberi manfaat kekebalan bagi bayi agar tidak mudah sakit, dan lamanya pemberian ASI eksklusif menjadi tanggung jawab ibu dan juga keluarga: suami, orang tua, mertua, dan tenaga kesehatan. Tujuan penelitian ini untuk mengetahui peranan keluarga dan petugas kesehatan terhadap lama menyusui pada bayi usia 12 bulan dengan 40 responden. Pengolahan dan analisa data menggunakan Analisa Ragam Regresi Linier Berganda. Hasil yang didapatkan, dukungan suami mempengaruhi lama menyusui pada bayi usia 12 bulan dengan Thitung $0,020<\mathrm{T} 0.05$ yaitu 0,984. Dukungan orang tua atau mertua dengan nilai Thitung 0,898 > T0.05 yaitu 0,375. Dukungan tenaga kesehatan sebesar Thitung 0,657 > T0,05 yaitu 2,156. Dapat disimpulkan bahwa dukungan tenaga kesehatan dan dukungan keluarga sangat berpengaruh pada lamanya pemberian ASI, dukungan suami kurang mempengaruhi lamanya pemberian ASI. Peran suami sangat diharapkan untuk mendukung pemberian ASI eksklusif, dan tetap ada banyak waktu dan cara untuk membantu dan mendukung keberhasilan ASI eksklusif walaupun suami bekerja, demi pemberdayaan istri atau perempuan dalam keluarga.
\end{abstract}

Kata Kunci : Peran keluarga, petugas kesehatan, lama menyusui

\begin{abstract}
Indonesia is one of developing countries with high Infant Mortality (IMR). IMR in 2017 counted as 10.294 cases (Indonesian Health Ministry) caused by infections and hypothermia. Early breastfeeding (IMD) and exclusive breastfeeding is efforts to reduce infectious IMR causes, since exclusive breastfeeding benefits immunity for infants so that they don't get sick easily, and exclusive breastfeeding length is responsibility for mothers and families: husbands, parents, in-laws, and health personnel. The purpose is knowing family role and health personnel towards breastfeeding duration for 12 month old baby with 40 respondents. Processing and data analysis using Multiple Linear Regression Analysis. The results obtained, husband support affects breastfeeding duration in 12 months old infants with Tcount 0,020< T0,05 is 0,984. Support parent or in-laws with value Tcount 0,898 > T0,05 is 0,375. Health personnel support amounted to Tcount 0,657 > T0,05 that is 2,156. It can be concluded that health personnel support and family support is very influential on breastfeeding duration, husband support less affect the breastfeeding duration. Husband role is desirable to support exclusive breastfeeding, and there remains plenty of time and means to help and support the exclusive breastfeeding success of husbands working, for women empowerment sake in family.
\end{abstract}

Keywords: Family role, health personnel, length of breastfeeding 


\section{PENDAHULUAN}

Indonesia merupakan salah satu negara berkembang dengan angka kematian bayi tertinggi. Angka kematian bayi tahun 2017 semester I sebesar 10.294 kasus. Berdasarkan data BPS, AKB Jawa Timur tahun 2016 sebesar 23,60, angka ini turun dari sebelumya tahun 2015 sebesar 24.00. Angka tersebut masih jauh dari target MDG's tahun 2015 sebesar 23 per 1.000 kelahiran hidup. Salah satu target Sustainable Development Goals (SDGs) adalah menurunnya angka kematian bayi (UNDP, 2015). Survei Demografi dan Kesehatan Indonesia (SDKI) 2012 menunjukkan bahwa angka kematian bayi di Indonesia adalah 32 per 1.000 kelahiran hidup (Kementerian kesehatan RI, 2012). Kematian bayi antara lain berkaitan dengan pemberian air susu ibu (ASI) eksklusif. Kementerian Kesehatan melaporkan bahwa sekitar 1,5 juta anak di Indonesia meninggal dan sebagian berhubungan dengan pemberian ASI eksklusif yang masih rendah, pemberian makanan pendamping ASI yang salah dan tidak tepat. ${ }^{1}$

Penurunan AKB mengindikasikan peningkatan derajat kesehatan masyarakat sebagai salah satu wujud keberhasilan pembangunan di bidang kesehatan. ${ }^{2}$ Upaya menurunan angka kematian bayi di suatu wilayah diperlukan upaya menurunkan angka kesakitan bayi terlebih dahulu karena angka kesakitan mempunyai peranan yang lebih penting dibandingkan dengan angka kematian. Angka kesakitan merupakan indikator penting dalam rangka penilaian dan perencanaan program untuk menurunkan kematian di suatu wilayah. Angka kesakitan tinggi maka akan memicu tingginya angka kematian. ${ }^{3}$

Bayi usia 0-12 bulan intensitas terkena penyakit lebih sering karena daya tahan tubuh masih rendah. ${ }^{4}$ Pemberian ASI eksklusif merupakan salah satu faktor yang dapat mencegah bayi dari penyakit infeksi antara lain diare, infeksi saluran nafas termasuk pneumonia. ${ }^{5}$

Menurut Dirjen Gizi dan KIA, keberhasilan ibu menyusui untuk terus menyusui bayinya sangat ditentukan oleh dukungan dari suami, keluarga, petugas kesehatan, masyarakat serta lingkungan kerja. $^{6}$ Pemberian ASI eksklusif pada bayi bukan hanya tanggung jawab ibu saja. Dukungan suami, keluarga dan masyarakat serta pihak terkait lainnya sangat dibutuhkan utnuk meningkatkan kembali pemberian ASI eksklusif pada bayi. Kepala keluarga, dalam hal ini suami memiliki tanggung jawab besar untuk memberikan dukungan. ${ }^{7}$

Dukungan keluarga yang baik dan dengan melakukan IMD secara bermakna berhubungan dengan pemberian ASI eksklusif oleh ibu yang beraktivitas dalam rumah. ${ }^{8}$ Hal ini menunjukkan betapa penting dukungan keluarga dan petugas kesehatan dalam pemberian ASI. Oleh karena itu penelitian ini bertujuan untuk melihat hubungan keluarga dan tenaga kesehatan dengan lamanya pemberian ASI pada bayi usia 12 bulan.

\section{METODE}

Penelitian ini menggunakan desain deskriptif dan eksploratif yang bertujuan untuk menguji hipotesa atau menjawab pernyataan yang berkaitan dengan current status dari objek yang diteliti dan untuk menguji suatu hipotesa penelitian, yaitu adanya hubungan peran keluarga dan petugas kesehatan dengan lama menyusui pada bayi usia 12 bulan.Penelitian ini dilaksanakan di Praktik Mandiri Bidan yang berada didesa Mangliawan Kecamatan Pakis Kabupaten Malang. Populasi penelitian sebanyak 40 orang ibu menyusui yang memiliki bayi usia 0-12 bulan. Metode pemilihan sampel nonprobabilitas atau secara tidak acak yaitu Purposive Judgement Sampling. Metode pengumpulan data yang digunakan adalah metode survey dengan menggunakan kuisioner sebagai alat pengumpulan data.

Kuesioner yang digunakan dengan metode terbuka dan metode tertutup (close-ended quesioner). Data yang diperoleh akan dilakukan proses Coding, scoring, transferring, tabulating. Analisis Data mengunakan analisis deskriptif (tabulasi silang) dan juga menggunakan model regresi linier berganda untuk mengatahui apakah ada peran suami, keluarga dan 
tenaga kesehatan dengan lama menyusui bayi usia 12 bulan. Deskripsi ini menggunakan Analisa Ragam Regresi Linier Berganda. tenaga kesehatan (variabel $\mathrm{X}_{3}$ ) dengan lama menyusui pada usia 12 bulan (variabel Y) menunjukkan hasil yang signifikan.

\section{HASIL DAN PEMBAHASAN}

Analisis ragam regresi linier berganda hubungan dukungan suami $\left(X_{1}\right)$, dukungan orang tua $\left(X_{2}\right)$, dukungan petugas kesehatan $\left(\mathrm{X}_{3}\right)$ dengan lama menyusui ASI Esklusif pada bayi usia 12 bulan (Y)

\begin{tabular}{cccccc}
\hline $\begin{array}{c}\text { Sumber } \\
\text { Keragaman }\end{array}$ & Derajad Bebas & Jumlah Kuadrat & Kuadrat Tengah & $\mathbf{T}_{\text {hitung }}$ & $\mathbf{T}_{\mathbf{0}, \mathbf{0 5}}$ \\
\hline Regresi & 3 & 16,038 & 5,346 & 0,761 & 0,524 \\
Galat & 36 & 253,062 & 7,030 & & \\
Total & 39 & 269,100 & & & \\
\hline
\end{tabular}

\section{Analisis ragam regresi linier berganda hubungan dukungan suami $\left(X_{1}\right)$, dukungan orang tua $\left(X_{2}\right)$, dukungan petugas kesehatan $\left(X_{3}\right)$ dengan lama menyusui ASI Esklusif pada bayi usia 12 bulan (Y)}

\begin{tabular}{lccc}
\hline \multicolumn{1}{c}{ Variabel } & Koefisien Regresi & $\mathbf{T}_{\text {hitung }}$ & $\mathbf{T}_{\mathbf{0 , 0 5}}$ \\
\hline Dukungan suami $\left(\mathrm{X}_{1}\right)$ & $-4,385$ & 0,020 & 0,984 \\
Dukungan orang tua atau mertua $\left(\mathrm{X}_{2}\right)$ & 0,247 & 0,898 & 0,375 \\
Dukungan tenaga kesehatan $\left(\mathrm{X}_{3}\right)$ & 0,257 & 0,657 & 0,156 \\
\hline
\end{tabular}

Penelitian dilakukan di Praktik Mandri Bidan wilayah Kec. Pakis Kabupaten Malang dengan jumlah 40 responden ibu menyusui yang memiliki bayi rentang usia kurang dari 12 bulan.

Dari hasil yang telah diperoleh nilai $\mathrm{F}_{\text {hitung }}(0,76)$ lebih besar dari nilai $\mathrm{F}_{0,05}(0,52)$. Dukungan suami $\left(\mathrm{X}_{1}\right)$, dukungan orang tua $\left(\mathrm{X}_{2}\right)$, dukungan tenaga kesehatan $\left(\mathrm{X}_{3}\right)$ mempunyai hubungan yang signifikan dengan lama menyusui pada bayi usia 12 bulan (Y).

Dari hasil yang telah diperoleh bahwa Nilai $\mathrm{T}_{\text {hitung }} 0,020$ yang lebih kecil dari $\mathrm{T}_{0,05}$ yaitu 0,984 artinya Dukungan suami (variabel X) dengan variabel Y (lama menyusui pada usia 12 bulan) menunjukkan hasil yang tidak signifikan.

Nilai $T_{\text {hitung }} 0,898$ yang lebih besar dari $T_{0,05}$ yaitu 0.375. Dukungan orang tua (variabel $\mathrm{X}$ ) dengan variabel Y (lama menyusui pada usia 12 bulan) menunjukkan hasil yang signifikan. Nilai $\mathrm{T}_{\text {hitung }} 0,657$ yang lebih besar dari $T_{\text {hitung }}$ yaitu 0,156 . Dukungan

\section{PEMBAHASAN}

Pada penelitian ini didapatkan bahwa dukungan suami tidak signifikan dengan lama menyusui pada usia 12 bulan. Penelitian ini sejalan denganpenelitian yang dilakukan oleh Ona dan kawan-kawan tahun 2015 dikatakan bahwa Hasil penelitian menunjukkan terdapat hubungan antara dukungan keluarga dengan perilaku menyusui eksklusif namun tidak terdapat hubungan antara dukungan suami dengan perilaku menyusui eksklusif.

Dukungan suami adalah salah satu bentuk interaksi yang didalamnya terdapat hubungan yang saling memberi dan menerima bantuan yang bersifat nyata yang dilakukan oleh suami terhadap istrinya. ${ }^{3}$ Pekerjaan suami juga menjadi pendorong dalam pemberian ASI eksklusif, dimana kesibukan suami dalam mencari nafkah menjadi salah satu hambatan untuk lebih terlibat dalam keluarga. ${ }^{9}$ Guna mengatasi 
hambatan ini, salah satu hal yang diperlukan adalah mempromosikan ASI eksklusif di tempat kerja suami dan mendorong suami ikut mendampingi pemeriksaan kehamilan, persalinan, dan saat kunjungan neonatal.

Dukungan orang tua mempunyai hubungan signifikan dengan lama menyusui pada usia 12 bulan. Hasil penelitian ini sejalan dengan penelitan yang dilakukan oleh Hesteria dan kawan kawan tahun 2016 di katakan dukungan keluarga yang baik dalam melakukan IMD (Inisiasi Menyusu Dini) secara bermakna berhubungan dengan pemberian ASI eksklusif oleh ibu yang beraktivitas dalam rumah, hal ini sejalan dengan penelitian yang dilakukan oleh Isroini tahun 2013 dikatakan bahwa terdapat hubungan yang signifikan antara pendidikan, pekerjaan, pengetahuan, dan sikap ibu, sertaperan petugas, keterpaparan media, peran suami, peran orang tua dengan pemberian ASI eksklusif. ${ }^{10}$ Peran orang tua merupakan faktor yang paling dominan terhadap pemberian ASI eksklusif setelah dikontrol oleh variabel pendidikan, pekerjaan, sikap, peran petugas, keterpaparan media dan peran suami. Keluarga adalah orang-orang terdekat ibu, dalam penelitian ini meliputi orang tua, mertua, dan saudarasaudara ibu. Menurut Sudiharto (2007), dukungan keluarga adalah dukungan untuk memotivasi ibu memberikan ASI saja kepada bayinya sampai usia 6 bulan termasuk memberikan dukungan psikologis kepada ibu dan mempersiapkan nutrisi yang seimbang kepada ibu. ${ }^{11}$ Friedman dalam Sudiharto (2007) menyatakan bahwa fungsi dasar keluarga antara lain adalah fungsi efektif, yaitu fungsi internal keluarga untuk pemenuhan kebutuhan psikososial, saling mengasuh, dan memberikan cinta kasih, serta saling menerima dan mendukung. ${ }^{12}$ Suami dan keluarga dapat berperan aktif dalam pemberian ASI dengan cara memberikan dukungan emosional atau bantuan praktis lainnya. ${ }^{13}$ Dukungan instrumental yang didapat dari keluarga terutama orang tua dan mertua ibu diantaranya adalah dengan memasakkan makanan yang dapat memperlancar ASI, seperti memasakkan sayur-sayuran dan sumber protein hewani. Ibu juga sering mendapatkan nasihat dari keluarga untuk memberikan ASI pada bayinya yang merupakan wujud dari dukungan penilaian serta mendapatkan juga dukungan emosional berupa mendengarkan keluhan-keluhan ibu selama menyusui.

Penelitian ini juga mengatakan bahwa dukungan tenaga kesehatan mempunyai pengaruh signifikan dengan lama menyusui pada usia 12 bulan. Menurut penelitian Septian dan kawan kawan tahun 2014 menunjukkan hasil yang sejalan dengan penelitian ini yaitu terdapat hubungan antara dukungan tenaga kesehatan dengan niat Ibu hamil dalam memberikan ASI Eksklusif di Wilayah Kerja Puskesmas Gondokusuman, Kota Yogyakarta. ${ }^{14}$ Untuk dapat menyusui ASI secara eksklusif. Dukungan petugas kesehatan tersebut dapat berupa penyuluhan tentang ASI Ekslusif dan Insiasi menyusui Dini (IMD). Peranan petugas kesehatan yang sangat penting dalam melindungi, meningkatkan, dan mendukung usaha menyusui ASI harus dapat dilihat dalam segi keterlibatannya yang luas dalam aspek sosial. $^{15}$

Hasil penelitian ini didapatkan tidak ada hubungan yang signifikan peran suami dalam keberhasilan lamanya pemberian pada bayi usia kurang 12 bulan sangat meresponi pernyataan Bailyn bahwa, dukungan seorang suami yang dengan tegas berpikiran bahwa ASI adalah yang terbaik, akan membuat ibu lebih mudah memberikan ASI Eksklusif pada bayinya. ${ }^{16}$

Friedman (1998) menjelaskan Dukungan informasional, keluarga berfungsi sebagai sebuah kolektor dan disseminator (penyebar) informasi tentang dunia. Suami sebagai kepala keluarga memberikan penjelasan tentang pemberian saran, sugesti, informasi yang dapat digunakan mengungkapkan suatu masalah. Manfaat dari dukungan ini adalah dapat menekan munculnya suatu stressor karena informasi yang diberikan dapat menyumbangkan aksi sugesti yang khusus pada individu. Beberapa aspek dalam dukungan ini adalah nasihat, usulan, saran, petunjuk dan pemberian informasi. 
Selain dukungan suami, keluarga dan tenaga kesehatan untuk ketercapaian keberhasilan pemeberian ASI maka perlu bentuk dukungan instrumental yaitu: penyediaan materi berupa pemberian pertolongan langsung seperti pemberian uang, barang, makanan serta pelayanan. Bentuk ini sangat membantu mengurangi stress karena ibu menyusui dapat langsung memecahkan masalahnya yang mungkin behubungan dengan materi. Dukungan instrumental sangat diperlukan terutama dalam mengatasi masalah yang terkait kebutuhan fisik ibu menyusui.

\section{KESIMPULAN DAN SARAN}

Penelitian ini menyimpulkan bahwa pengaruh yang sangat kuat keberhasilan lamanya pemberian ASI adalah pada peran tenaga kesehatan dan keluarga (ibu atau mertua). Sedangkan peran suami tidak signifikan yang artinya suami belum berperan dalam lamanya pemberian ASI pada bayi usia kurang dari 12 bulan. Meskipun secara statistic menunjukkan bahwa tidak ada hubungan yang bermakna antara dukungan suami dengan lamanya pemberian ASI pada bayi usia kurang 12 bulan. Namun dalam beberapa hal suami juga memberi dukungan instrumental pada keberhasilan pemberian ASI pada bayi usia kurang dari 12 bulan di PMB Kecamatan Pakis Kabupaten Malang. Disimpulkan dari penelitian ini bahwa dukungan suami mempunyai hubungan tidak signifikan dengan lama menyusui pada usia 12 bulandan dukungan orang tua mempunyai hubungan signifikan dengan lama menyusui pada usia 12 bulan. serta dukungan tenaga kesehatan mempunyai hubungan signifikan dengan lama menyusui pada usia 12 bulan.

Penelitian ini merekomendasikan kepada Suami sebagai kepala keluarga diharapkan menjalankan perannya sebagai ayah menyusui, dan sebagai support system bagi ibu agar dapat memberikan ASI eksklusif. Karena seorang suami yang dengan tegas berpikiran bahwa ASI adalah yang terbaik, akan membuat ibu lebih mudah memberikan ASI Eksklusif pada bayinya.
Diharapkan pula adanya dukungan yang maksimal dari keluarga terutama suami bagi isterinya yang sedang menyusui. Dukungan ini sangat diperlukan yaitu adanya jalinan kerjasama diantara keluarga termasuk suami, isteri dan keluarga lainnya sehingga ibu dapat memberikan air susu ibu secara eksklusif. Pemberian ASI esklusif sangat tergantung dari dukungan atau keterlibatan suami pada isterinya, dimana dukungan dan peran suami secara psikhologis akan meningkatkan produksi ASI dan akan berdampak pada pemberian ASI yang cukup bagi bayinya, sehingga dapat mempersiapkan anak yang sehat, cerdas, ketahanan immunitas yang baik sehingga mempersiapkan anak yang pandai dan berdampak pada perannya di masyarakat serta kemajuan bangsa.

\section{DAFTAR PUSTAKA}

1. Kementerian Kesehatan RI. Acara puncak Pekan ASI Sedunia (PAS) tahun 2014. Jakarta: Kemenkes RI; 2014.

2. Profil Kesehatan Provinsi Jawa Timur. 2011. Angka kematian Bayi (AKB) Provinsi Jawa Timur

3. Hidayat, A. (2005). Pengantar Ilmu Keperawatan Anak Jilid I. Jakarta: Salemba Medika

4. Abraham H. Laisina, D. Takumansang-Sondakh, J. M. Wantania. 2007. Faktor Risiko Kejadian Asma pada Anak Sekolah Dasar di Kecamatan Wenang Kota Manado. Bagian IKA Fakultas Kedokteran UNSRAT/RSU Prof. Dr. R. D. Kandou Manado. Sari Pediatri, Vol. 8, No. 4, Maret 2007: 299 -30

5. IDAI. Air Susu Ibu dan Pengendalian Infeksi. Jakarta; 2013.

6. Budiharja. (2011, Maret 29). BPPSDMK Pusat Komunikasi Publik Sekretariat Jenderal Kementerian Kesehatan RI. Retrieved Desember 5, 2011, from Seminar Jurnal Keperawatan Maternitas . Volume 1, No. 2, November 2013; 93-101 100 "Peningkatan Pemberian Air Susu Ibu (ASI) Eksklusif Bagi Bayi Dalam Mendukung MDGs" di Jakarta, Selasa 29 Maret 2011.

7. Pemprov DKI Jakarta. (2010). Pemberian ASI Eksklusif Perlu Ditingkatkan. Jakarta: Pemprov DKI Jakarta.

8. Hesteria dkk. 2016.Faktor-Faktor yang Berhubungan dengan Pemberian ASI Ekslusif pada Ibu Beraktivitas dalam Rumah di Kabupaten Tabanan. Public Health and Preventive Medicine Archive. Desember 2016 Volume 


\section{(2). Hal 179- 185}

9. Ramadani, M., Hadi, E.N. (2010). Dukungan Suami dalam Pemberian ASI Eksklusif di Wilayah Kerja Puskesmas Air Tawar Kota Padang Sumatera barat.Jurnal Kesehatan Masyarakat Nasional, Vol. 4. No. 6

10. Isroni A. 2013. Determinan Pemberian ASI Eksklusif Pada Ibu Menyusui. Jurnal Health Quality Vol. 4 No. 1, Nopember 2013, Hal. 1 -76

11. Sudiharto. (2007). Asuhan Keperawatan Keluarga dengan Pendekatan Keperawatan Transkultural. Jakarta: EGC

12. Friedman, M., Bowden, V. r., \& Jones, E.G. (2010). Buku Ajar KeperawatanKeluarga; Riset, Teori dan Praktik.Jakarta : EGC.

13. Roesli, U. (2007). Mengenal ASI Eksklusif. Jakarta: Trubus Agriwidaya.

14. Septian EDJ, Zahroh S, Antono S. 2014. Dukungan Tenaga Kesehatan Untuk Meningkatkan Niat Ibu Hamil Dalam Memberikan ASI Eksklusif di Wilayah Kerja Puskesmas Gondokusuman, Kota Yogyakarta. Jurnal Promosi Kesehatan Indonesia. Agustus 2014. Vol. 9 (2). Hal 196- 305

15. Noer ER, Siti F, Muis, Roni A. 2011. Praktik Inisiasi Menyusu Dini dan Pemberian ASI Eksklusif Studi Kualitatif pada Dua Puskesmas, Kota Semarang. Media Medika Indonesiana. Volume 45, Nomor 3

16. Bailyn L. The slow-burn way to the top: Some thoughts on the early years of organizational careers. In Derr C. B. (Ed.). Work, family, and the career. New York: Praeger, 1980, 94-105. 